\title{
Is the Fetus an Unborn Baby? The Moral Dilemma of Reproductive Rights: A Commentary
}

\author{
Hani Raoul Khouzam* \\ Department of Mental Health, USA
}

ISSN: 2640-9666

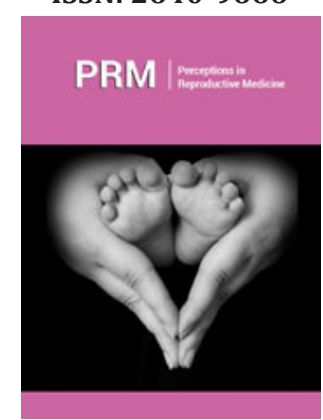

*Corresponding author: Hani Raoul Khouzam, Department of Health, USA

Submission: 海July 05, 2019

Published: 制July 17, 2019

Volume 3 - Issue 4

How to cite this article: Hani Raoul Khouzam. Is the Fetus an Unborn Baby? The Moral Dilemma of Reproductive Rights: A Commentary. Perception in Reproductive Medicine.3(4). PRM.000566.2019.

DOI: 10.31031/PRM.2019.03.000566

Copyright@ Hani Raoul Khouzam, This article is distributed under the terms of the Creative Commons Attribution 4.0 International License, which permits unrestricted use and redistribution provided that the original author and source are credited.

\section{Commentary}

The purpose of this commentary is to clarify an alternative point of view in regard to the semantic differentiation that has been promoted as true fact which claims that a fetus is not a real person and as such cannot be called or treated as a baby. Advocates of the reproductive rights insist that a fetus is not a baby unless a passage of rights is earned by leaving the mother womb. As a consequence of this assumption the fetus is not a person and does not possess any right in deciding on whether to live or to be terminated. The fetes is described as a part of the mother's body and she is the only person that have the right to decide on whether she wishes to keep this part of her body until she delivers a live baby or to exercise her rights to get rid of what she considers as an unwanted pregnancy and aborts the unborn baby. Although abortion is a legal procedure and ending an unborn baby's life is not consider an act of murder and women who abort their unborn baby are not tried for a murder, it seems contradictory to other legal notions that are widely accepted by most human beings and that is to charge a person with committing a double murder if the action of that person either accidently or intentionally lead to a death of a pregnant woman. How can it be that aborting an unborn baby is not considered a voluntary ending of a human life, while ending a life of pregnant woman is considered a murder of two lives. These facts are described by the United States law of the land which recognizes a child in utero as a legal victim, if injured or killed during the commission of any of over 60 listed federal crimes of violence.

The law defines "child in utero" as "a member of the species Homo sapiens, at any stage of development, who is carried in the womb [1]. To help shed some light on this dilemma; it would be appropriate to illustrate some prevailing notions. "Life" is a property that distinguishes between that which has signaled as a self-sustaining processes and that which does not, by exhibiting such things as cellular organization, homeostasis, metabolism, growth, response to stimuli, etc. Something does not have life occurs when either those biological functions have ceased (death) or when those functions were never possessed in the first place such as in the case of inanimate objects [2]. "Homo sapiens" a member of the human species and the fetus has a human DNA and can't possibly be classified as any species other than homo sapiens, so it is obvious then that the fetus is a person.

\section{Does the fetus as a person have assigning rights?}

To claim to a right to live, a person should be able to live independently and since the fetus is only able to live because of being within the mother's womb; therefore, any claim to a "right" to live is completely dependent on the mother. However, the same must be true for all who have physical and mental disabilities that prevent them from independent life and entail them to receive support and help from the community at large. So why is then the fetus singled out as not deserving life due to the inability to live independent of the mother's womb. Besides, with the recent scientific research in reproductive services, it would be feasible for a fetus to grow outside of the mother's body, in what have been called artificial wombs. 


\section{Does a pregnant mother have obligations to her Fetus?}

Being pregnant means having a growing new life within the womb. Whether the fetus is a person or not, and whether the laws of the land take a position on abortion or not, it's arguable that a pregnant mother have some obligation to her fetus even if that conception was unplanned or unwanted. Although this obligation does not carry a strong standing toward eliminating the option of aborting an unborn baby, it may pose challenges to the ethical and moral choices of pursuing abortion as the only solution of rejecting an unwanted or unplanned pregnancies [3].

\section{The ethics of reproductive rights}

It is difficult and politically charged to argue that abortion is not within the realm of a mother right to exercise her autonomy and control over her own body. This right to choose would lead to the unavoidable consequence of terminating a pregnancy and resulting into the death of the fetus. Since autonomy exists as an ethical necessity, it also creates the dilemma of how far that autonomy would be allowed to extend and to prohibit any legal authority from forcing the would-be mother of carrying a full-term pregnancy until the birth of a baby? So even if the fetus is a person and abortion is considered unethical, it shouldn't be prevented through unethical means.

\section{Ethical obligations toward the fathers}

Should the would-be-mother give the would -be-father the freedom of whether the pregnancy is carried to term? Since fathers have an ethical obligation to support their babies, should they have an ethical claim on whether their babies are allowed to be born or aborted? Ideally, fathers should be consulted, and what would be the outcome if they do not want their unborn babies to be aborted?

\section{Summary}

The termination of the life of a fetus or unborn baby through elective abortion as a fundamental reproductive right of women to exercise control over their own body does not solve the moral dilemma of denying the personhood of the unborn baby until delivery from the mother's womb. Elective abortion creates a significant number of important, fundamental ethical questions in regard to the nature of personhood, the nature of perceived human rights, intimate relationships, personal autonomy, the extent of state authority over personal decisions, and more. All of this means that it is very important for the advocates of reproductive rights and providers of reproductive health services to reconsider their views about the personhood of the unborn babies who may be silently pleading for a chance to live beyond the confines of their mothers' womb because after all is being argued ,these babies are "Fearfully and Wonderfully Created" [4].

\section{References}

1. (2004) The unborn victims of violence act (Public Law 108-212).

2. Cunningham FG, Leveno KJ, Bloom SL, Hauth JC, Rouse DJ, et al. (2009) The morphological and functional development of the fetus. In: Williams (Ed.), Obstetrics (23 ${ }^{\text {rd }}$ edn), McGraw-Hill, New York, USA.

3. Khouzam HR (2015) Could elective abortion precipitate mental health consequences in its recipients and providers? Journal of Depression and Anxiety 4(4): 196.

4. New International Version (2011) Psalm, Zondervan, Michigan, USA, 139: $17-18$ 